\title{
Influence of NFKB inhibitors on IL-1 $\beta$-induced chemokine CXCL8 and -10 expression levels in intestinal epithelial cell lines: glucocorticoid ineffectiveness and paradoxical effect of PDTC
}

\author{
Yeruva Sunil • Giuliano Ramadori • Dirk Raddatz
}

Accepted: 29 October 2009 / Published online: 18 November 2009

(C) The Author(s) 2009. This article is published with open access at Springerlink.com

\begin{abstract}
Purpose Activation of intestinal epithelial cell (IEC) nuclear factor $\mathrm{\kappa B}(\mathrm{NF} \kappa \mathrm{B})$ and the consequent chemokine upregulation are crucial events in inflammatory bowel disease (IBD) pathogenesis. Not much is known about the consequences of NFKB inhibition in terms of chemokine expression in intestinal cells. Therefore, we aimed to evaluate the efficacy of compounds known to disrupt the NFKB pathway on NFKB transcriptional activity and CXCL8 and CXCL10 gene expression in intestinal cell lines.

Methods The influence of NFKB inhibitors (dexamethasone, pyrrolidine dithiocarbamate (PDTC) and BAY 11-7082) on IL- $1 \beta$-induced NF $\kappa B$ transcriptional activity was investigated by transient transfection of Caco-2 cells with an NFKBsecreted alkaline phosphatase reporter plasmid. Il-1 $\beta$ stimulated CXCL8 and CXCL10 mRNA and protein expression and was studied in Caco-2 and HT29 cells in the presence and absence of the NFKB inhibitors by quantitative real-time polymerase chain reaction and enzyme-linked immuno-
\end{abstract}

Y. Sunil $\cdot$ G. Ramadori $\cdot$ D. Raddatz $(\bowtie)$

Centre for Internal Medicine, Department of Gastroenterology

and Endocrinology, University of Goettingen,

Goettingen, Germany

e-mail: draddat@gwdg.de

Present Address:

Y. Sunil

Department of Gastroenterology, Hepatology and Endocrinology,

Hannover Medical School,

Carl Neuberg Strasse-1,

30625 Hannover, Germany sorbent serologic assay, respectively. To reveal alternative signalling cascades, experiments were also performed in the presence of the p38MAPK inhibitor SB 203580 and the ERK inhibitor PD 98059.

Results Dexamethasone did not downregulate chemokine expression sufficiently, probably due to a lack of glucocorticoid receptors in these cells. While BAY11-7082 inhibited chemokine expression, PDTC led to a paradoxical upregulation of CXCL8 in Caco-2 cells, which could be prevented by inhibition of p38MAPK.

Conclusion These data explain the frequent unresponsiveness of IBD to glucocorticoid treatment and suggest that alternative NFKB inhibition in IECs might be of use in IBD therapy. Drug development based on measuring anti-NFKB activity might be misleading and should therefore also include studies on relevant gene products.

Keywords NFKB - Intestinal epithelial cells · CXCL10 . CXCL8 PDTC

\section{Introduction}

In the past few years, there has been increasing interest in how cytokines, bacteria and bacterial polymers induce intestinal epithelial cell (IEC) gene expression. In IECs, gene expression must be tightly regulated to avoid overreaction to normal microbial flora while at the same time remaining responsive to harmful pathogens. Nuclear factor $\kappa \mathrm{B}(\mathrm{NF} \kappa \mathrm{B})$ is a crucial player in maintaining intestinal barrier integrity since its tonic stimulation is essential for defensin production [1]. On the other hand, $\mathrm{NF} K \mathrm{~B}$ is involved in the transcriptional activation of several 
genes involved in mucosal inflammation and in contrast to normal mucosa is activated, both in macrophages and in epithelial cells of inflamed intestinal mucosa [2], suggesting a prominent role in inflammatory bowel disease (IBD) pathogenesis.

The NFkB family is comprised of a group of transcription factors defined in part by their ability to bind a specific DNA sequence first identified in the enhancer of the immunoglobulin $\kappa$ light chain gene $[3,4]$. NFkB exists as a heterodimer comprising RelA (p65) and NFKB1 (p50) subunits in most cells; this heterodimer is the most potent gene transactivator of the NFKB family [5]. NFKB is activated by a variety of agents, such as cytokines, growth factors, T cell mitogens, oxidative stress, bacteria, viruses and their products. Upon activation by various stimuli, NFkB transcriptionally regulates many cellular genes involved in early inflammatory responses, including the chemokines CXCL8 [6] and CXCL10 [7].

CXCL8 (IL-8) is a proinflammatory CXC chemokine associated with the promotion of neutrophil chemotaxis and degranulation [8]. CXCL8 protein is secreted by a variety of cell types, including IECs $[9,10]$. CXCL8 has also been shown to play an important but non-specific role in the pathogenesis of IBD, and its mRNA has been shown to be restricted to areas with histological signs of inflammatory activity and mucosal destruction [11].

CXCL10 is a CXC chemokine that binds to the CXCR3 chemokine receptor, expressed mainly by activated $\mathrm{CD} 4^{+}$ memory $\mathrm{T}$ cells, which produce a $\mathrm{T}$ helper cell 1 pattern of cytokine production [12]. CXCL10 is also known for its anti-angiogenic properties in cancers [13]. It has also been shown that IECs express CXCL10 mRNA, suggesting that the intestinal epithelium can play a role in modulating physiologic and pathologic $\mathrm{T}$ cell-mediated mucosal inflammation [14].

Increased NFKB activity was found in the IECs of IBD patients [2], suggesting that targeting $\mathrm{NF} \kappa \mathrm{B}$ activity in these cells might be an attractive goal for therapeutic intervention. Although glucocorticoids are known to inhibit $\mathrm{NF} K \mathrm{~B}$ activity [15], not much is known about their effect in IECs in terms of expression of inflammation-related genes. The same is true for other NFKB-inhibiting compounds like pyrrolidine dithiocarbamate (PDTC) and BAY11-7082, an irreversible inhibitor of IKB $\alpha$ phosphorylation. IL- $1 \beta$ is a potent inducer of NFKB. High concentrations of IL-1 $\beta$ are found both in Crohn's disease and ulcerative colitis intestine [16]. Previous studies have shown that CXCL8 [9] and CXCL10 [7] are upregulated by IL-1 $\beta$ in intestinal cells. We aimed, therefore, to test the efficacy of different inhibitors of NFKB on IL-1 $\beta$-induced NFKB activity and CXCL8 and CXCL10 expression in an intestinal model system, utilising the established intestinal cell lines Caco-2 and HT29.

\section{Materials and methods}

\section{Reagents}

Recombinant IL-1 $\beta$ was purchased from Roche Applied Science (Mannheim, Germany). p38 MAPK inhibitor SB203580, MEK inhibitor PD98059 and BAY 11-7082, a specific inhibitor of $N F K B$, were purchased from Calbiochem (San Diego, CA, USA), and the NFkB inhibitor PDTC was purchased from Sigma-Aldrich (Germany).

Cell culture and stimulation protocols

The human colon adenocarcinoma cell lines Caco-2 and HT29 were obtained from DPZ (Braunschweig, Germany). Caco-2 cells were grown in Eagle's minimal essential medium (BioWhittaker) containing 20\% foetal calf serum (FCS) supplemented with $100 \mathrm{U} / \mathrm{ml}$ each of penicillin and streptomycin and $1 \%$ non-essential amino acids at $37^{\circ} \mathrm{C}$ with $5 \% \mathrm{CO}_{2}$. HT29 cells were grown in Roswell Park Memorial Institute medium containing $10 \%$ FCS and $100 \mathrm{U} / \mathrm{ml}$ penicillin and streptomycin at $37^{\circ} \mathrm{C}$ with $5 \% \mathrm{CO}_{2}$.

Assay for activation of NFKB

Transient transfection with pNFKB-secreted alkaline phosphatase (SEAP; a reporter plasmid in which NFKB promoter elements are linked to the gene coding for secretory alkaline phosphatase) was used for assaying NFKB activity.

Caco-2 cells were plated in 24 -well plates $24 \mathrm{~h}$ before transfection (Nunc, Roskilde, Denmark) at a density of $50,000 /$ well in $1 \mathrm{ml}$ medium. After $24 \mathrm{~h}$, the cells were transfected using the non-liposomal formulation FuGENE (Roche Molecular Biochemicals, Mannheim, Germany). On the day of transfection, fresh medium was added. FuGENE was added to the plasmid DNA at a ratio of $3 \mu 1 / \mu \mathrm{g}$ DNA. FuGENE was pre-diluted in $100 \mu \mathrm{l}$ serum-free medium and added dropwise to the concentrated plasmid DNA. After $15 \mathrm{~min}$ at room temperature, the mixture was added to the cells. The cells received $200 \mathrm{ng}$ pNF kB-SEAP (BD Biosciences, Clontech, Palo Alto, CA, USA)/well. Twenty-four hours after transfection, the cells were treated with PDTC $(0.2,2$ and $20 \mu \mathrm{g} / \mathrm{ml}$, which are equivalent to final concentrations of 1.2, 12 and $120 \mu \mathrm{M}$ ), BAY11-7082 $(1,10$ and $100 \mu \mathrm{M})$, SB203580 and PD98059 for $1 \mathrm{~h}$ and then stimulated with IL-1 $\beta(1 \mathrm{ng} / \mathrm{ml})$ for $6 \mathrm{~h}$. Finally, cell supernatants were collected, and SEAP assays were performed as per the manufacturer's protocol.

RNA and protein expression studies

For stimulation, IECs were plated into 6-well plates at a density of $5 \times 10^{5}$ cells per well and grown until they 
reached $70-80 \%$ confluence. One hour prior to the stimulation, cells were pre-treated with one of the following: dexamethasone $(1 \mu \mathrm{M})$, PDTC $(0.2,2$ or $20 \mu \mathrm{g} / \mathrm{ml})$, BAY $11-$ $7082(1,10$ or $100 \mu \mathrm{M})$, SB203580 $(10 \mu \mathrm{M})$ or PD98059 $(10 \mu \mathrm{M})$. Cells were then stimulated with IL-1 $\beta(1 \mathrm{ng} / \mathrm{ml})$ for either 1 or $4 \mathrm{~h}$ for mRNA expression studies or for $24 \mathrm{~h}$ for enzyme-linked immunosorbent serologic assay (ELISA) assays.

RNA was isolated using the Qiagen RNeasy Mini Kit (Qiagen, Hilden, Germany), according to the manufacturer's protocol. The RNA concentration was determined photometrically using a Gene Quant RNA/DNA calculator (Pharmacia, Freiburg, Germany). RNA was subsequently used for real-time polymerase chain reaction (PCR). Reverse transcription of mRNA was performed using $1 \mu \mathrm{g}$ of total cellular RNA, as described previously [17].

PCR was carried out using gene-specific primers (Invitrogen, Karlsruhe, Germany) for human CXCL8 (forward 5'-ATG ACT TCC AAG CTG GCC G-3', reverse 5'-GCT GCA GAA ATC AGG AAG GC-3'), CXCL10 (forward 5'-CCA GAA TCG AAG GCC ATC AA-3', reverse 5'-CAT TTC CTT GCT AAC TGC TTT CAG-3') and $\beta$-actin (forward 5'-CTG GCA CCC AGC ACA ATG-3', reverse 5'-CCG ATC CAC ACG GAG TAC TTG-3') in an ABI Prism 7000 system.

PCR reactions were set up with $\operatorname{Sybr}^{\circledR}$ Green PCR Mastermix, containing $0.3 \mu \mathrm{mol} / \mathrm{l}$ of each primer and $1 \mu \mathrm{l}$ of reverse transcription product in a $25-\mu 1$ volume. A twostep amplification protocol was chosen, consisting of initial denaturation at $95^{\circ} \mathrm{C}$ for 10 min followed by 45 cycles of $15 \mathrm{~s}$ denaturation at $95^{\circ} \mathrm{C}$ and $30 \mathrm{~s}$ annealing/extension at $60^{\circ} \mathrm{C}$. Finally, a dissociation protocol was performed to control for specificity of amplification products. Relative expression of each chemokine was then calculated using the comparative threshold-cycle method, as described earlier [18]. mRNA gene expression is presented as fold increase calculated in relation to unstimulated cells, after normalisation against $\beta$-actin. Glucocorticoid receptor (GR) mRNA content was quantified in Caco-2 and HT29 cells as described previously [18].

Supernatants of Caco-2 and HT29 cultures were collected $24 \mathrm{~h}$ after stimulation with IL-1 $\beta$, and concentrations of CXCL8 and CXCL10 in the supernatants were measured by ELISA (Rnd Systems, Wiesbaden, Germany), following protocols provided by the manufacturer.

Statistical analysis

Statistical analyses were carried out using the Prism software packet (version 3.0, Graphpad Software, San Diego, CA, USA). Comparisons between two or more treatment groups were made with the unpaired $t$ test or analysis of variance, where appropriate. In case of RNA expression, a log transformation was performed beforehand. Statistical differences were regarded as significant at a $p$ value below 0.05 . Data are expressed as means \pm standard error of the mean.

\section{Results}

PDTC and BAY11-7082 inhibit IL-1 $\beta$-mediated pNF $\kappa B-S E A P$ reporter gene activity in Caco-2 cells

In order to show whether PDTC and BAY11-7082 could function in inhibiting NFKB in Caco-2 cells, we performed reporter assays utilising an NFKB-SEAP reporter, which harbours NFKB binding elements. IL- $1 \beta$ treatment resulted in a $4.01 \pm 0.416$-fold increase in reporter gene activity. This induction was inhibited in a dose-dependent manner by PDTC and BAY11-7082. Both stimulated and spontaneous NF KB activities were half-maximally inhibited by PDTC at a range between 0.2 and $2 \mu \mathrm{g} / \mathrm{ml}$ and by BAY11-7082 between 1 and $10 \mu \mathrm{M}$ (Fig 1).

Effect of dexamethasone on cytokine-mediated CXCL8 and CXCL10 mRNA and protein expression

Chemokine mRNA and protein levels were induced by IL$1 \beta$. Dexamethasone served to reduce IL-1 $\beta$-induced CXCL8 mRNA to $82.7 \pm 0.5 \%$ when compared to an untreated control. However, although there was a trend, there was no significant reduction of CXCL8 protein by dexamethasone treatment (Fig 2a). IL-1 $\beta$-induced CXCL10 mRNA expression was reduced to $81.3 \pm 9.4 \%$ of control levels in the presence of dexamethasone. Also, CXCL10 protein levels were not significantly downregulated by dexamethasone (Fig. 2b). In HT29 cells, dexamethasone had no influence on CXCL8 or CXCL10 expression, either at the mRNA or protein level (data not shown).

Glucocorticoid receptor (GR) mRNA expression in Caco-2 and HT29 cells

GR was shown to be expressed in both cell lines. However, its expression level was extremely low (four orders of magnitude lower) in HT29 cells compared to Caco-2 cells (Fig. 3).

PDTC and BAY11-7082 effects on IL-1 $\beta$-mediated CXCL8 mRNA expression and protein secretion in Caco-2 cells

PDTC, a known inhibitor of NF $K B$, was expected to inhibit IL- $1 \beta$-induced CXCL8 mRNA expression, as CXCL8 expression is regulated by NFKB. To prove this, CXCL8 
a

$\mathrm{NF} \kappa \mathrm{B}$ activity/PDTC

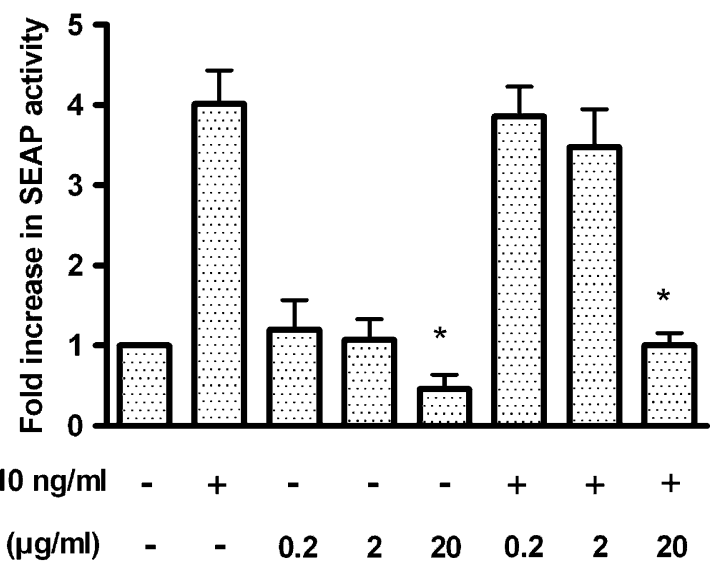

b
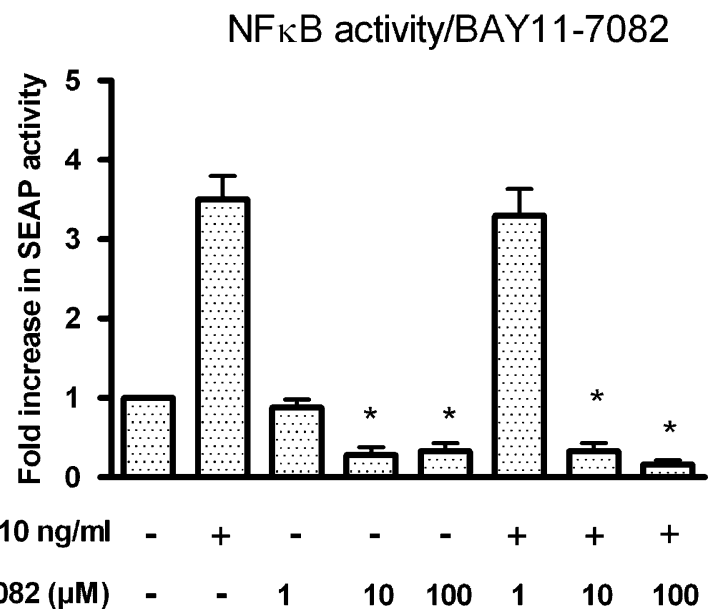

Fig. 1 Dose-dependent effects of pyrrolidine dithiocarbamate (PDTC) (a) and BAY11-7082 (b) on IL-1 $\beta$-mediated pNFkB-secreted alkaline phosphatase (SEAP) reporter gene activity in Caco-2 cells. Caco-2 cells were transiently transfected with pNFkB-SEAP plasmid. Twenty-four hours after transfection, cells were pre-treated for $1 \mathrm{~h}$ with increasing concentrations of PDTC or BAY11-7082, as indicated. After $1 \mathrm{~h}$, cells were stimulated with IL-1 $\beta$ or phosphate buffer solution as a control. Six hours after stimulation, cell supernatants were collected, and SEAP activity was measured. Data are shown as means \pm standard error of the mean of four individual experiments performed in duplicate for each sample. Asterisk corresponds to $p<0.05$ compared to IL- $1 \beta$ stimulation alone

mRNA and protein expression levels were measured in IL$1 \beta$-stimulated Caco-2 cells pre-treated with PDTC.

Surprisingly, IL-1 $\beta$ induced CXCL8 mRNA expression was enhanced by PDTC in a dose-dependent manner. IL-1 $\beta$ led to a $117 \pm 9.1$-fold increase in CXCL8 mRNA, which was enhanced to $150 \pm 21.6$ - and $262 \pm 62.35$-fold increases in the presence of PDTC at 2 and $20 \mu \mathrm{g} / \mathrm{ml}$, respectively. This observation was also confirmed at the protein level by ELISA of culture supernatants. PDTC alone did not stimulate CXCL8 expression (Fig. 4a).

In contrast, BAY11-7082, a specific inhibitor of IKB phosphorylation, inhibited IL- $1 \beta$-mediated CXCL8 mRNA expression and protein secretion in a dose-dependent manner. IL-1 $\beta$-induced CXCL8 mRNA expression increased by $120.85 \pm 33.7$-fold after $1 \mathrm{~h}$. In the presence of BAY117082 at concentrations of 1,10 and $100 \mu \mathrm{M}$, IL-1 $\beta$-induced CXCL8 mRNA levels were inhibited to $119.02 \pm 31.35$-, $8.19 \pm 3.73$ - and $0.97 \pm 0.15$-fold increases, respectively. CXCL8 secretion induced by IL-1 $\beta$ reached $522.49 \pm$ $46.68 \mathrm{pg} / \mathrm{ml}$ after $24 \mathrm{~h}$. In the presence of BAY11-7082 (1, 10 and $100 \mu \mathrm{M})$, IL-1 $\beta$-induced CXCL8 protein secretion was inhibited to $429.17 \pm 17.09,328.98 \pm 21.81$ and $244.84 \pm$ $5.67 \mathrm{pg} / \mathrm{ml}$, respectively (Fig. 4b).

Comparison of the effects of the NFKB inhibitor PDTC and MAP kinase inhibitors SB203580 and PD98059 on IL-1 $\beta$-mediated CXCL8 mRNA expression and protein secretion in Caco-2 and HT29 cells

Since IL- $1 \beta$-mediated CXCL8 gene expression is also under the control of MAP kinases, we examined the effect of the MAPK inhibitors SB203580 (p38 MAPK inhibitor) and PD98059 (MEK inhibitor) on IL-1 $\beta$-induced CXCL8 gene expression in Caco-2 and HT29 cells and compared these effects with that of PDTC. Pre-treatment of both Caco-2 and HT29 cells with SB203580 $(10 \mu \mathrm{M})$ led to a significant reduction in IL-1 $\beta$-induced CXCL8 mRNA expression and protein secretion. In Caco- 2 cells, IL-1 $\beta$ $(1 \mathrm{ng} / \mathrm{ml})$ increased CXCL8 mRNA levels by $19.75 \pm 2.52$ fold, which was reduced to $7.52 \pm 0.77$-fold in the presence of SB203580. IL-1 $\beta$-induced CXCL8 secretion in Caco-2 cells was reduced from $286.79 \pm 32.99$ to $55.50 \pm 34.09 \mathrm{pg} / \mathrm{ml}$ in the presence of SB203580 $(10 \mu \mathrm{M})$. PD98059 also inhibited IL1- $\beta$-induced mRNA and protein expression by approximately $50 \%$. A combination of both PDTC $(20 \mu \mathrm{g} / \mathrm{ml})$ and SB203580 $(10 \mu \mathrm{M})$ did not inhibit IL-1 $\beta$-induced CXCL8 mRNA expression or protein secretion in Caco-2 cells. However, PDTC-mediated enhancement of IL-1 $\beta$ induced CXCL8 mRNA expression and protein secretion was inhibited by SB203580, suggesting a role for p38 MAPK (Fig. 5a).

We then wondered whether this enhancement effect of PDTC was cell-line dependent, so we used HT29 cells to check the effect of PDTC on IL-1 $\beta$-mediated CXCL8 mRNA expression and protein secretion. In the case of HT29 cells, PDTC did not inhibit IL-1 $\beta$-induced CXCL8 gene expression. It also did not enhance CXCL8 expression, as was the case for Caco-2 cells. In HT29 cells, CXCL8 was induced $11.49 \pm 2.39$-fold by IL- $1 \beta$, which was reduced to $2.03 \pm 0.59$-fold in the presence of SB203580 and to $2.26 \pm 0.59$-fold in the presence of PD98059. IL-1 $\beta$ induced CXCL8 protein levels in HT29 cells were reduced from $5,163.30 \pm 777.04$ to $1,157.72 \pm 179.59$ and $1,718.86 \pm$ $166.67 \mathrm{pg} / \mathrm{ml}$ in the presence of SB203580 and PD98059, respectively (Fig. 5b). 
Fig. 2 Influence of dexamethasone on IL-1 $\beta$-induced CXCL8 (a) and CXCL10 (b) mRNA (left panel) and protein (right panel) expression. Caco- 2 cells $\left(5 \times 10^{5}\right.$ per well) were plated into 6 -well plates and grown for $24 \mathrm{~h}$. Cells were then pre-treated with dexamethasone $(1 \mu \mathrm{M})$ for $1 \mathrm{~h}$ before stimulation with IL- $1 \beta$ $(1 \mathrm{ng})$. Cells were harvested at 1 (CXCL8) and $4 \mathrm{~h}$ (CXCL10), total RNA was isolated and real-time reverse transcriptionpolymerase chain reaction was performed. For measuring protein expression, stimulation was performed for $24 \mathrm{~h}$. Data are shown as the fold increase compared to the baseline controls and represent the means of three individual experiments \pm standard error of the mean. Asterisk corresponds to $p<0.05$ compared to controls a CXCL8 mRNA

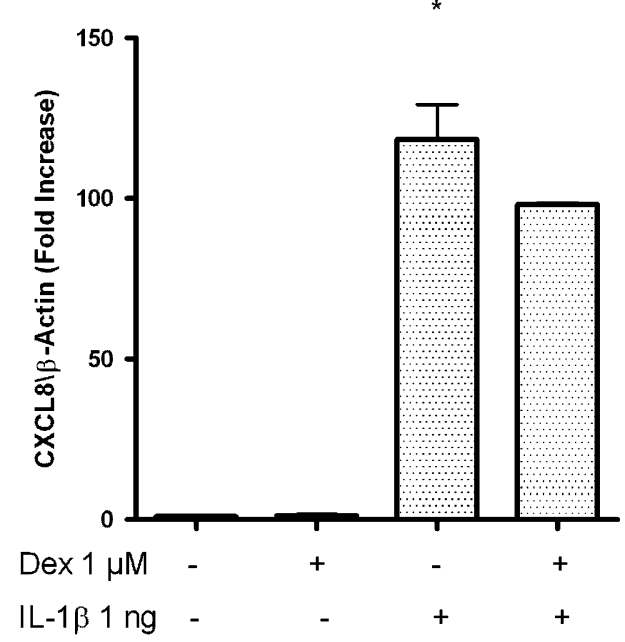

b CXCL10 mRNA

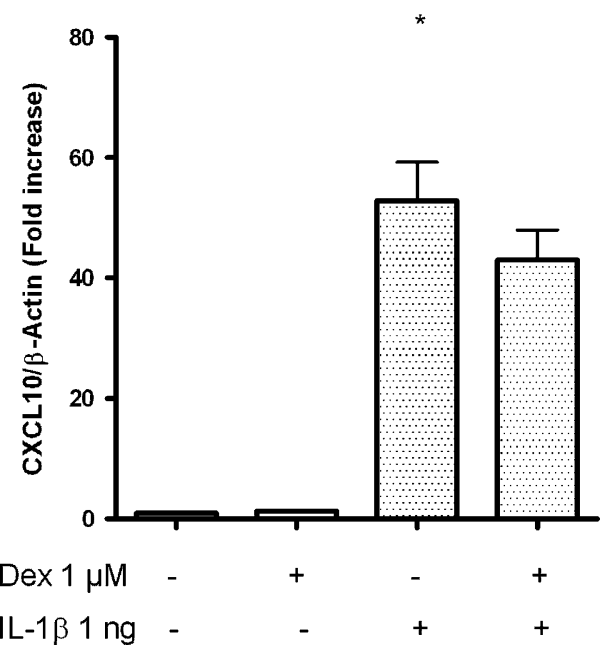

CXCL8 protein

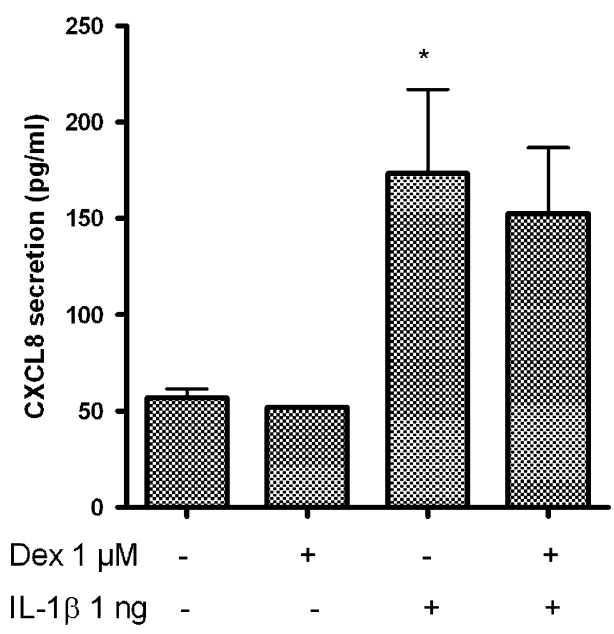

CXCL10 protein

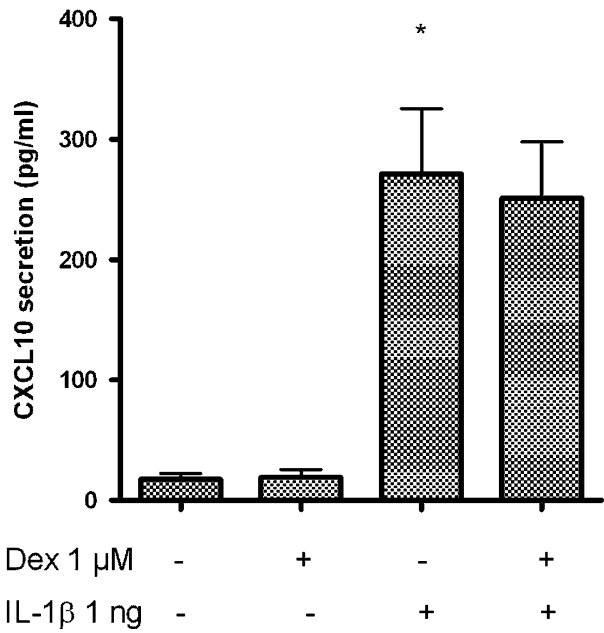

Comparison of the effects of the NFKB inhibitor PDTC and MAP kinase inhibitors SB203580 and PD98059 on IL-1 $\beta$-mediated CXCL10 mRNA expression and protein secretion in Caco-2 and HT29 cells

In contrast to CXCL8, IL-1 $\beta$-induced CXCL10 expression was downregulated by PDTC in Caco- 2 cells. IL-1 $\beta(1 \mathrm{ng} / \mathrm{ml})$ induced a $55.89 \pm 4.84$-fold increase in CXCL10 mRNA, which was reduced to $45.42 \pm 4.66-, 9.51 \pm 0.72-, 17.03 \pm 3.21$ and $9.94 \pm 1.30$-fold increases in the presence of PDTC $(20 \mu \mathrm{g} / \mathrm{ml})$, SB203580 $(10 \mu \mathrm{M})$, PD98059 $(10 \mu \mathrm{M})$ and SB203580 $(10 \mu \mathrm{M})$ together with PDTC $(20 \mu \mathrm{g} / \mathrm{ml})$, respectively (Fig. 6a). IL-1 $\beta$-induced CXCL10 secretion in Caco-2 cells was reduced from $220.66 \pm 13.86$ to $134.33 \pm$ $28.42,84.46 \pm 16.82,150.66 \pm 6.06$ and $93.21 \pm 23.21 \mathrm{pg} / \mathrm{ml}$ in the presence of PDTC, SB203580, PD98059 and SB203580 and PDTC together, respectively.

In HT29 cells, CXCL10 mRNA expression and protein secretion induced by IL-1 $\beta$ were inhibited significantly by
PDTC. IL-1 $\beta$-induced CXCL10 mRNA by $11.49 \pm 2.39$ fold. In the presence of the inhibitors PDTC and SB203580, IL-1 $\beta$-induced CXCL10 mRNA expression was reduced to $5.12 \pm 1.50$ and $10.76 \pm 1.15$, respectively. Surprisingly, PD98059, either alone or in the presence of IL-1 $\beta$, led to an upregulation (up to $46.12 \pm 10.97$-fold) of CXCL10 mRNA, but this effect was not seen at the level of IL1 $\beta$ induced CXCL10 protein secretion. In the presence of PDTC, SB203580 and PD98059, IL-1 $\beta$-induced CXCL10 protein secretion was reduced from $86.88 \pm 26.83$ to $34.93 \pm$ $10.83,8.70 \pm 4.38$ and $14.54 \pm 14.54 \mathrm{pg} / \mathrm{ml}$, respectively (Fig. 6b).

\section{Discussion}

Steroids are known to inhibit NFKB activity, both by direct protein-protein interaction with the GR [19] and induction 


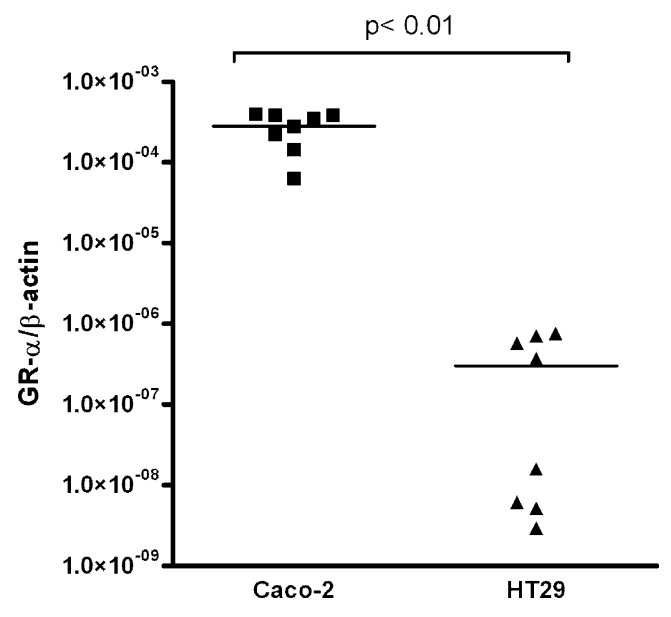

Fig. 3 Glucocorticoid receptor $\alpha$ mRNA expression in Caco-2 and HT29 cells. Cells $\left(5 \times 10^{5}\right.$ per well) were plated in 6-well plates, grown for $24 \mathrm{~h}$ and harvested. RNA was isolated and reverse transcribed to cDNA. Real-time polymerase chain reaction was performed with gene-specific primers for GR $\alpha$. $\beta$-actin was used as an internal control. Data shown represent the GR $\alpha / \beta$-actin mRNA ratios of four independent experiments performed in duplicate. The horizontal bars represent the means

of $\mathrm{I} \kappa \mathrm{B} \alpha$, an $\mathrm{NF} \kappa \mathrm{B}$ inhibitor, via GR activity [15]. The present data confirm earlier observations that colonic epithelial cells are largely unresponsive to glucocorticoids. Dexamethasone was not capable of significantly downregulating CXCL8 or CXCL10 expression. This is in accordance with our previous findings showing only an incomplete transrepression of NFKB activity in transient reporter gene assays in Caco-2 cells stimulated with IL-1 $\beta$, although the level of GR expression in those cells is comparable to peripheral blood mononuclear cells [20]. Nevertheless, the number of available GR molecules seems to be insufficient, since transrepression of NFKB can be restored by GR overexpression [20]. In HT29 cells, there is a clear lack of GRs, as suggested by the low abundance of GR mRNA (more than 1,000-fold less than in Caco-2 cells).

In contrast to steroid-sensitive IBD patients, where initial $\mathrm{NF} K \mathrm{~B}$ activity normalises, NFKB was shown to remain activated in IECs of IBD patients who are resistant to steroid therapy [21], suggesting that GR signalling might be disturbed, possibly due to a lack of functional GRs. Therefore, inhibiting NFKB with alternative compounds is of importance in treating IBD. Although 5-aminosalicylic acid is known to inhibit NFKB [22], it is of limited use in severe ulcerative colitis or Crohn's disease, and patients do not profit from its additional oral use when systemic steroids are given. Although PDTC and BAY11-7082 are not intended for pharmacological use in humans, they are paradigms for NFKB inhibitors and are widely used in experimental settings.
PDTC, a thiol-containing agent, is known to be a stable anti-oxidant and has been widely used to inhibit the activation of NFKB in a variety of cell lines. In the present study, both PDTC and BAY11-7082 inhibited IL-1 $\beta$ induced NFKB reporter gene activity in a dose-dependent manner in Caco-2 cells, revealing their inhibitory effect on NF $K B$ activation. However, treatment of Caco- 2 cells with PDTC resulted in an dose-dependent enhancement of IL$1 \beta$-induced CXCL8 mRNA expression, rather than its inhibition, which seems to contradict previous studies that showed IL-1 $\beta$ was able to induce the CXCL8 gene via NFKB in Caco-2 cells [23]. ELISA experiments also showed that this effect was persistent at the level of protein synthesis and secretion. In contrast, IL- $1 \beta$-induced CXCL8 expression and secretion were inhibited in a dose-dependent fashion by BAY11-7082.

Previous studies with PDTC revealed that it is not only involved in inhibiting NF $\kappa B$ but could also activate other signalling pathways, depending on the cellular context. In rat mesangial cells, PDTC induced gene expression of stromelysin through tyrosine kinase-mediated activation of the transcription factor AP-1 [24]. Additionally, ICAM-1 expression was upregulated by PDTC in human endothelial cells via activation of the AP-1 pathway [25]. In vascular smooth muscle cells, PDTC induced G1 phase cell-cycle arrest, partially by activating p38 MAPK [26]. Since IL-1 $\beta$ induced CXCL8 gene expression was also shown to be regulated by $\mathrm{p} 38$ MAPK via the CXCL8 promoter in Caco-2 cells [27], we aimed to elucidate the role of p38 MAPK in PDTC- and IL-1 $\beta$-induced CXCL8 gene expression.

As expected, inhibition of $\mathrm{p} 38$ MAPK with the inhibitor SB205380 led to an inhibition of spontaneous and IL-1 $\beta$ induced CXCL8 expression and secretion in Caco-2 cells. SB203580 inhibited PDTC-mediated enhancement of spontaneous and IL- $1 \beta$-induced CXCL8 expression, suggesting that PDTC activates the p38 MAPK pathway and, consequently, CXCL8 gene expression.

These results might be explained by the presence of single AP-1 binding site in addition to the two NFKB binding sites in the CXCL8 promoter [28]. Previously, it has been shown that IL-1 $\beta$-mediated activation of p38 MAPK leads to AP-1 activation [29]. In addition to activation of transcription, post-transcriptional mechanisms contribute to the induction of CXCL8 gene expression [30]. Holtmann et al. have shown that the p38 MAP kinase pathway contributes to induction of CXCL8 synthesis by stabilising its mRNA [28]. Therefore, the activation of p38 MAPK by PDTC may lead to an enhancement of IL- $1 \beta$-induced CXCL8 gene expression in Caco-2 cells by stabilising CXCL8 mRNA.

In HT29 cells, PDTC neither inhibited nor enhanced the IL-1 $\beta$-induced CXCL8 expression and secretion, whereas SB203580 and PD98059 had inhibitory effects, suggesting 
Fig. 4 Dose-dependent effects of pyrrolidine dithiocarbamate (PDTC) (a) and BAY11-7082 (b) on IL-1 $\beta$-induced CXCL8 mRNA expression (left panels) and protein secretion (right panels) in Caco-2 cells. Caco-2 cells $\left(5 \times 10^{5}\right.$ per well) were plated in 6-well plates and grown for $24 \mathrm{~h}$. Cells were then pre-treated either with $0.2,2$ or $20 \mu \mathrm{g}$ of PDTC or 1,10 and $100 \mu \mathrm{M}$ BAY11-7082 per millilitre of culture medium for $1 \mathrm{~h}$ before stimulation with IL-1 $\beta(1 \mathrm{ng} / \mathrm{ml})$. Cells were harvested after $1 \mathrm{~h}$, and CXCL8 mRNA expression was measured by quantitative reverse transcription-polymerase chain reaction. For protein measurements, cell supernatants were collected after $24 \mathrm{~h}$, and enzyme-linked immunosorbent serologic assays for CXCL8 protein were performed. Data shown represent the mean of four individual experiments \pm standard error of the mean performed in duplicate. Single asterisk corresponds to $p<0.05$, and double asterisks correspond to $p<0.005$ compared to IL-1 $\beta$ stimulation alone a

CXCL8 mRNA

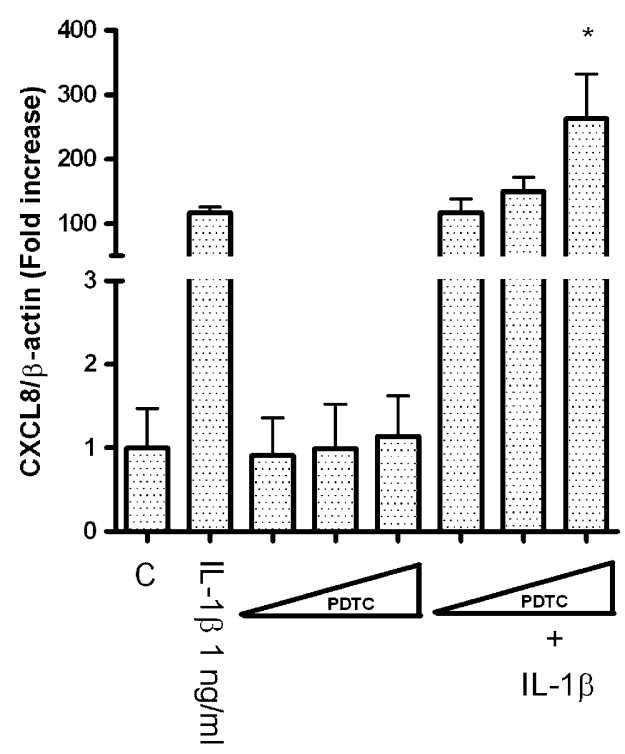

b

CXCL8 mRNA

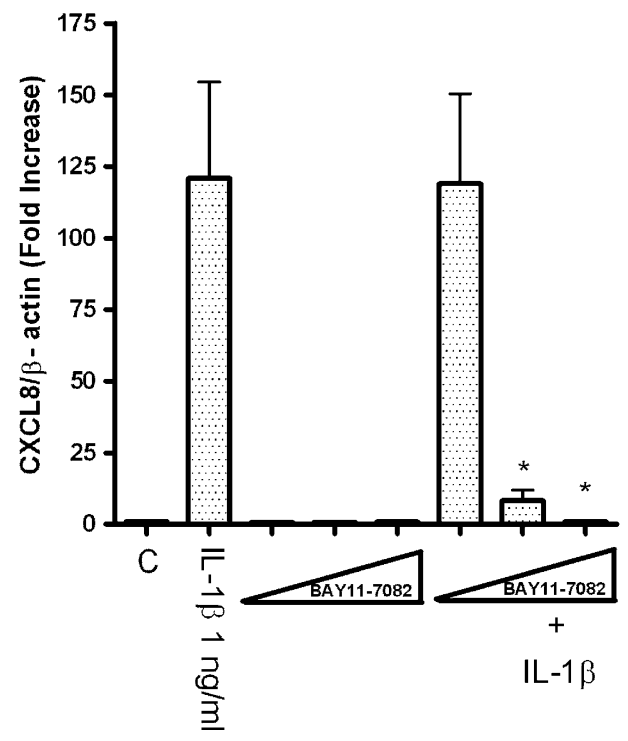

CXCL8 protein

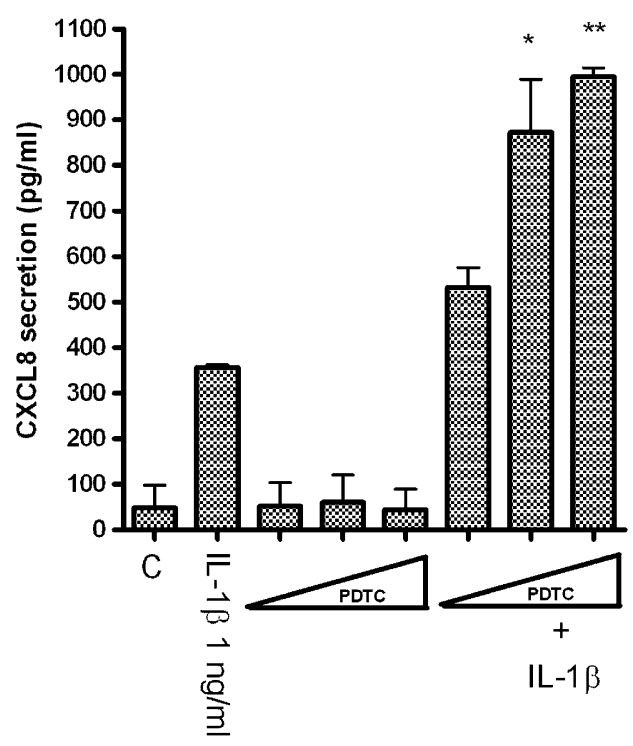

CXCL8 protein

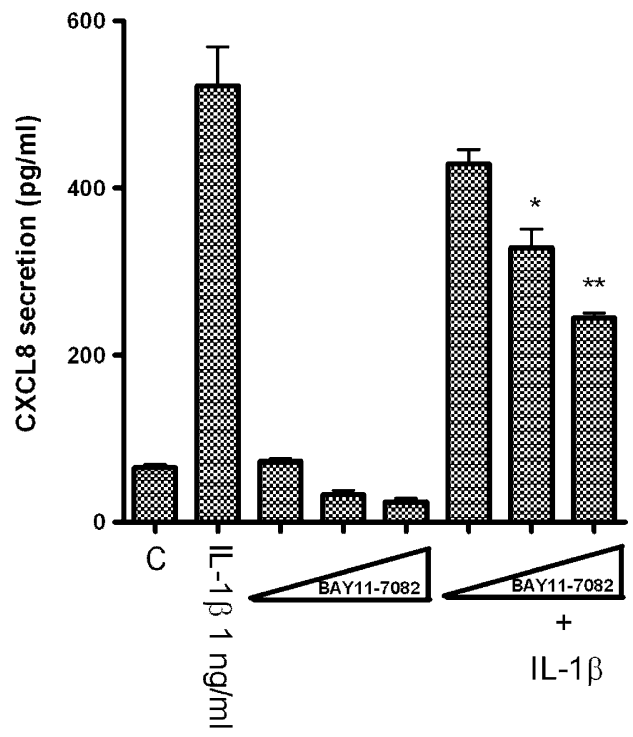

that the enhancing effect of PDTC on IL- $1 \beta$-induced CXCL8 gene expression as cell-line dependent.

IL-1 $\beta$ is known to induce CXCL10 gene expression in Caco-2 cells through NFKB [7]. To find out if the enhancing effect of PDTC on IL-1 $\beta$-induced CXCL8 gene expression was restricted to the CXCL8 gene, we investigated the role of PDTC on IL- $1 \beta$-induced CXCL10 gene expression in Caco-2 and HT29 cells as well. Both realtime PCR and ELISA experiments revealed that PDTC inhibited IL-1 $\beta$-induced CXCL10 gene expression in both Caco-2 and HT29 cells. The enhancing effect of PD98059 on IL-1 $\beta$-induced CXCL10 gene expression in HT29 cells may be a result of the activation of other regulatory pathways that stabilise CXCL10 mRNA. However, this effect was not seen at the level of protein synthesis. Inhibiting the p38 MAPK and MEK pathways resulted in the inhibition of IL-1 $\beta$-induced CXCL10 gene expression in Caco-2 cells.

In conclusion, these data suggest that colonic epithelial cells are unresponsive to glucocorticoids. Among the tested compounds, only BAY11-7082 was able to downregulate CXCL8 and -10 in both cell lines. Although PDTC proved to inhibit NFKB-driven transcriptional activity, it led to an increase in CXCL8 expression in Caco-2 cells. This unexpected phenomenon is most likely due to activation of p38 MAPK, since it was sensitive to the MAPK inhibitor 
a

Caco-2 mRNA
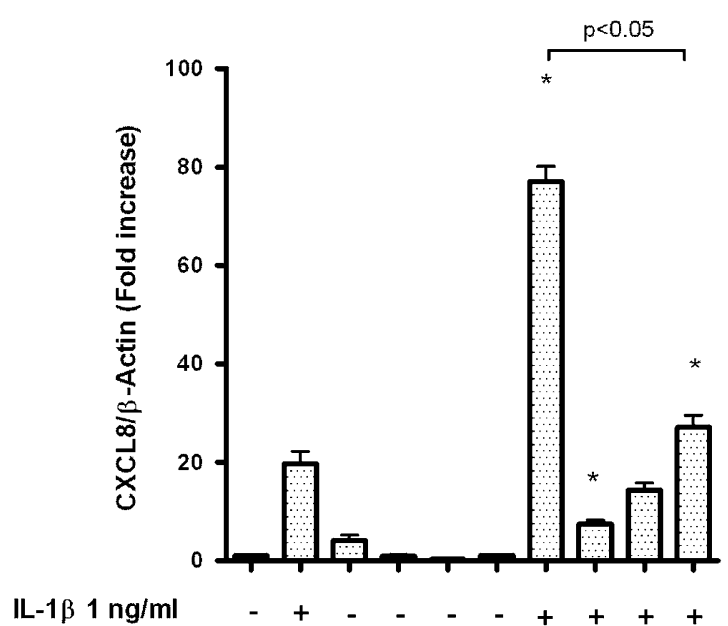

PDTC $20 \mu \mathrm{g} / \mathrm{ml} \quad-\quad-\quad+\quad-\quad-\quad+\quad+\quad-\quad-\quad+$

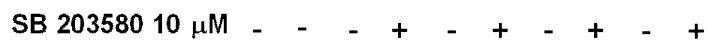

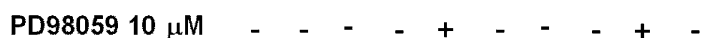

b

HT29 mRNA

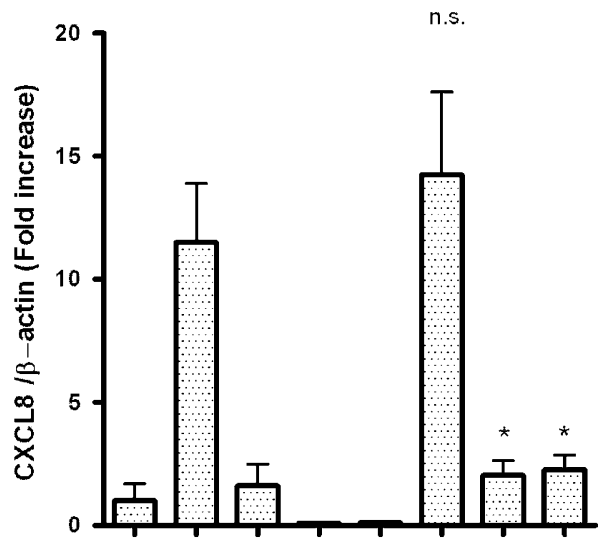

IL-1 $\beta 1 \mathrm{ng} / \mathrm{ml}$

PDTC $20 \mu \mathrm{g} / \mathrm{ml} \quad-\quad-\quad+\quad-\quad+\quad+\quad-$

SB $20358010 \mu \mathrm{M}-\mathrm{C}_{-} \quad-\quad+\quad-\quad-\quad+\quad-$

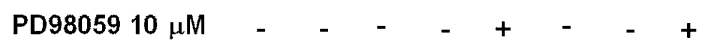

Fig. 5 Comparison of the effects of the NFkB inhibitor pyrrolidine dithiocarbamate (PDTC) and MAP kinase inhibitors SB203580 and PD98059 on IL-1 $\beta$-mediated CXCL8 mRNA expression (left panel) and protein secretion (right panel) in Caco-2 (a) and HT29 (b) cells. Cells $\left(5 \times 10^{5}\right.$ per well) were plated in 6-well plates and grown for $24 \mathrm{~h}$. Cells were then pre-treated with $20 \mu \mathrm{g} / \mathrm{ml}$ of PDTC, $10 \mu \mathrm{M}$ of SB203580 or $10 \mu \mathrm{M}$ of PD98059 for $1 \mathrm{~h}$ before stimulation with IL-

SB203580. Application of NFKB inhibitors may be a useful adjunct to steroid therapy in cases of suspected epithelial chemokine expression. However, NFKB-inhibiting compounds might activate alternative inflammatory pathways,
Caco-2 protein

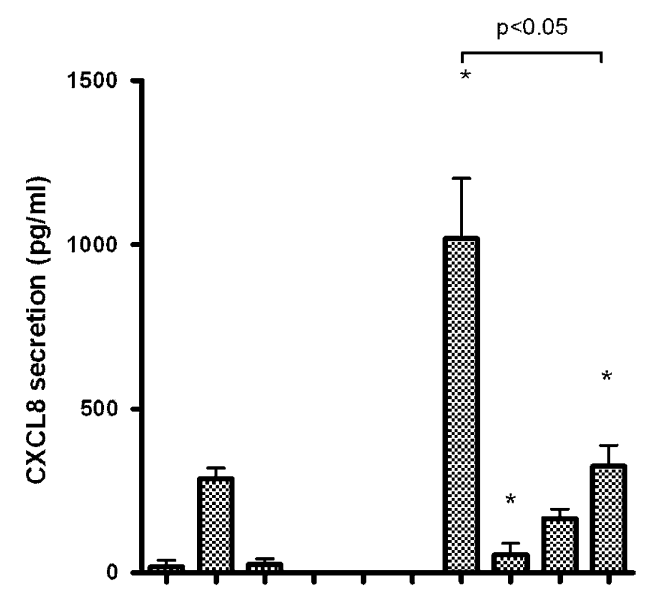

IL-1 $\beta 1 \mathrm{ng} / \mathrm{ml}$

PDTC $20 \mu \mathrm{g} / \mathrm{ml}$

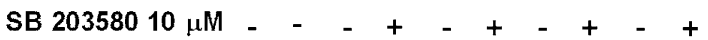

PD98059 $10 \mu \mathrm{M}-\mathrm{C}_{-} \quad-\quad+\quad-\quad-\quad+\quad$

HT29 protein

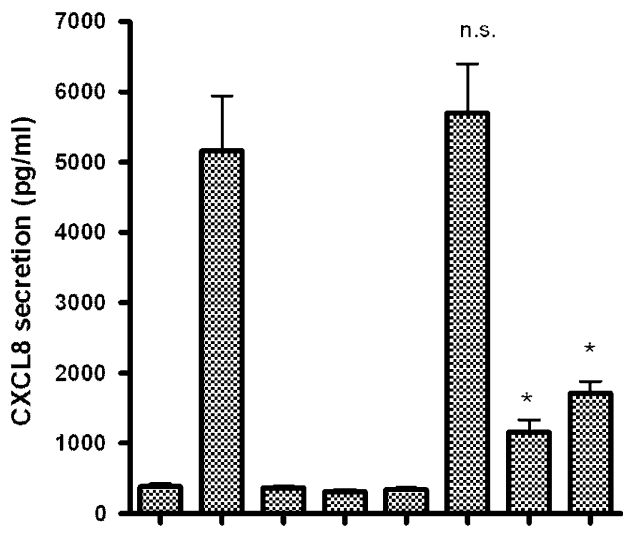

$\mathrm{IL}-1 \beta 1 \mathrm{ng} / \mathrm{ml}$

PDTC $20 \mu \mathrm{g} / \mathrm{ml}$

SB $20358010 \mu \mathrm{M}$

PD98059 $10 \mu \mathrm{M}$

$1 \beta$ for $4 \mathrm{~h}$ (for mRNA expression) or $24 \mathrm{~h}$ (for protein levels). CXCL8 mRNA expression was measured by quantitative reverse transcriptionpolymerase chain reaction. CXCL8 protein levels were measured from cell supernatants by enzyme-linked immunosorbent serologic assay. Data shown represent the mean of four individual experiments \pm standard error of the mean performed in duplicate. Asterisk corresponds to $p<0.05$ compared to IL- $1 \beta$ stimulation, $n s$ not significant

as has been shown in the case of PDTC. Therefore, drugscreening strategies based purely on measuring NF $\kappa B$ activity should be regarded cautiously and should include testing for relevant inflammatory gene products like CXCL8. 
a

Caco-2 mRNA

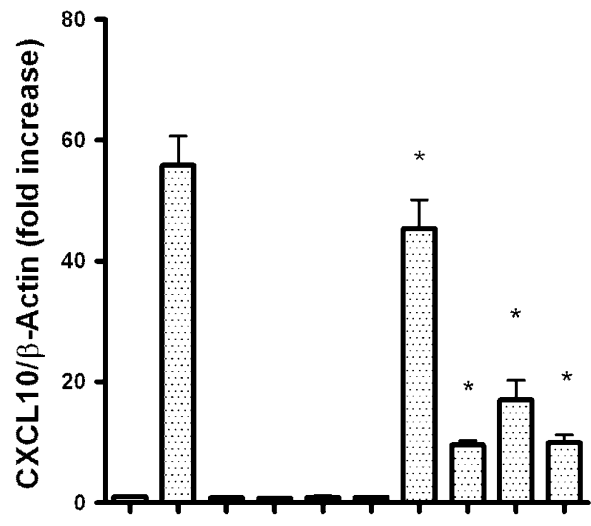

IL-1 $\beta 1 \mathrm{ng} / \mathrm{ml}$

PDTC $20 \mu \mathrm{g} / \mathrm{ml}$

SB $20358010 \mu \mathrm{M}$

PD98059 $10 \mu \mathrm{M}$

b

HT29 mRNA

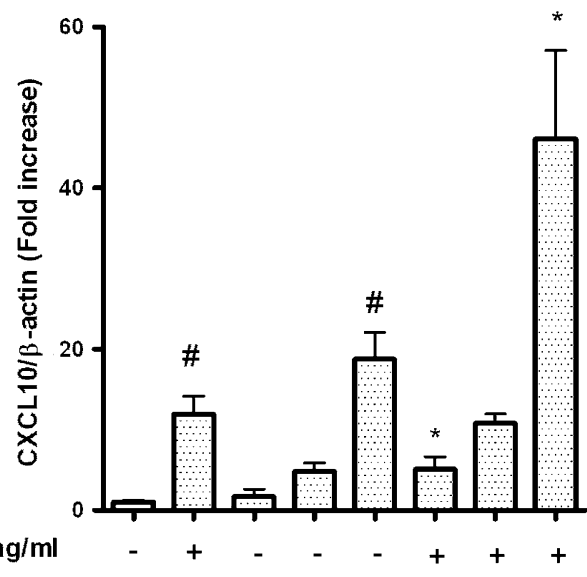

\section{$\mathrm{IL}-1 \beta 1 \mathrm{ng} / \mathrm{ml}$}

PDTC $20 \mu \mathrm{g} / \mathrm{ml}$

SB $20358010 \mu \mathrm{M}$ -

PD98059 $10 \mu \mathrm{M}$

Fig. 6 Comparison of the effects of the NFKB inhibitor pyrrolidine dithiocarbamate and MAP kinase inhibitors SB203580 and PD98059 on IL-1 $\beta$-mediated CXCL10 mRNA expression (left panels) and protein secretion (right panels) in Caco-2 (a) and HT29 (b) cells. Cell culture and stimulation conditions were as in Fig. 5. CXCL10 mRNA was measured by quantitative reverse transcription-polymerase chain

Recent studies in mouse conditional knockout models, in which NFKB signalling was ablated specifically in IECs, could show that a primary NFKB signalling defect in IECs disrupts immune homeostasis in the gastrointestinal tract, causing an inflammatory-bowel-disease-like phenotype [31], suggesting that a certain level of NFKB activation is necessary to keep epithelial barrier function. Remarkably partial disruption of $\mathrm{NF} K \mathrm{~B}$ signalling as achieved by
Caco-2 protein

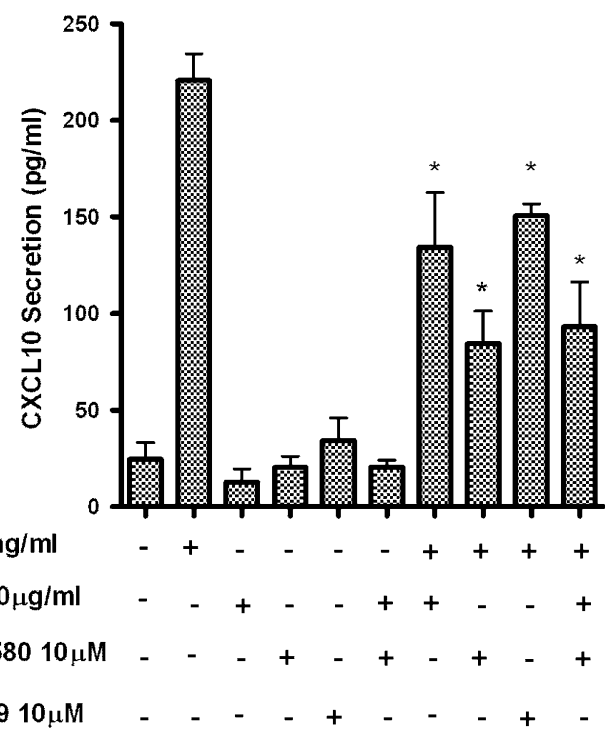

HT29 protein

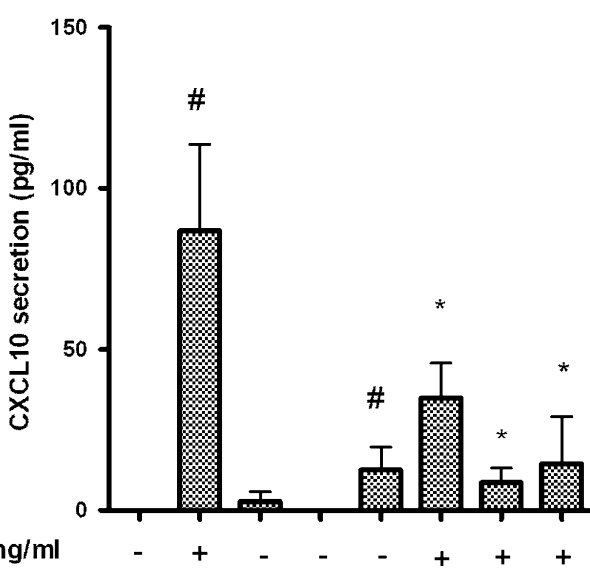

\section{IL-1 $\beta 1 \mathrm{ng} / \mathrm{ml}$}

PDTC $20 \mu \mathrm{g} / \mathrm{ml}$

SB $20358010 \mu \mathrm{M}$.

PD98059 $10 \mu \mathrm{M}$

reaction and CXCL10 protein by enzyme-linked immunosorbent serologic assay. Data shown represent the mean of four individual experiments \pm standard error of the mean performed in duplicate. Asterisk corresponds to $p<0.05$ compared to IL1 $\beta$ alone, number sign corresponds to $p<0.05$ compared to unstimulated controls

knocking out IKK $\beta$, one important upstream activator of $\mathrm{NF} K \mathrm{~B}$ in macrophages resulted in a significant decrease in tumour size in a mouse model of colitis-associated cancer, probably by inhibition of paracrine growth factors. In the same model, IKK $\beta$ knockout in enterocytes, although not abolishing inflammation, prevented development of colonic cancer, via an increase in apoptosis [32]. Inhibition of $\mathrm{NF} K \mathrm{~B}$ may therefore be effective in prevention of colitis- 
associated cancer. Nevertheless, keeping in mind the important role of $\mathrm{NF} K \mathrm{~B}$ in promoting intestinal barrier function and innate immune response care has to be taken employing NFKB inhibiting compounds in IBD therapy restricting its use to perpetuating inflammation with a state of $\mathrm{NF} \kappa \mathrm{B}$ overactivation.

Open Access This article is distributed under the terms of the Creative Commons Attribution Noncommercial License which permits any noncommercial use, distribution, and reproduction in any medium, provided the original author(s) and source are credited.

\section{References}

1. Voss E, Wehkamp J, Wehkamp K, Stange EF, Schroder JM, Harder J (2006) NOD2/CARD15 mediates induction of the antimicrobial peptide human beta-defensin-2. J Biol Chem 281:2005-2011

2. Rogler G, Brand K, Vogl D, Page S, Hofmeister R, Andus T, Knuechel R, Baeuerle PA, Scholmerich J, Gross V (1998) Nuclear factor kappaB is activated in macrophages and epithelial cells of inflamed intestinal mucosa. Gastroenterology 115:357-369

3. Grilli M, Chiu JJ, Lenardo MJ (1993) NF-kappa B and Rel: participants in a multiform transcriptional regulatory system. Int Rev Cytol 143:1-62

4. Baldwin AS Jr (1996) The NF-kappa B and I kappa B proteins: new discoveries and insights. Annu Rev Immunol 14:649-683

5. Ruben SM, Narayanan R, Klement JF, Chen $\mathrm{CH}$, Rosen CA (1992) Functional characterization of the NF-kappa B p65 transcriptional activator and an alternatively spliced derivative. Mol Cell Biol 12:444-454

6. Roebuck KA (1999) Regulation of interleukin-8 gene expression. J Interferon Cytokine Res 19:429-438

7. Yeruva S, Ramadori G, Raddatz D (2008) NF-kappaB-dependent synergistic regulation of CXCL10 gene expression by IL-1beta and IFN-gamma in human intestinal epithelial cell lines. Int $\mathrm{J}$ Colorectal Dis 23:305-317

8. Struyf S, Gouwy M, Dillen C, Proost P, Opdenakker G, Van Damme J (2005) Chemokines synergize in the recruitment of circulating neutrophils into inflamed tissue. Eur J Immunol 35:1583-1591

9. Fusunyan RD, Quinn JJ, Ohno Y, MacDermott RP, Sanderson IR (1998) Butyrate enhances interleukin (IL)-8 secretion by intestinal epithelial cells in response to IL-1beta and lipopolysaccharide. Pediatr Res 43:84-90

10. Kim H, Lim JW, Kim KH (2001) Helicobacter pylori-induced expression of interleukin-8 and cyclooxygenase-2 in AGS gastric epithelial cells: mediation by nuclear factor-kappaB. Scand J Gastroenterol 36:706-716

11. Banks C, Bateman A, Payne R, Johnson P, Sheron N (2003) Chemokine expression in IBD. Mucosal chemokine expression is unselectively increased in both ulcerative colitis and Crohn's disease. J Pathol 199:28-35

12. Loetscher M, Gerber B, Loetscher P, Jones SA, Piali L, ClarkLewis I, Baggiolini M, Moser B (1996) Chemokine receptor specific for IP10 and mig: structure, function, and expression in activated T-lymphocytes. J Exp Med 184:963-969

13. Proost P, Schutyser E, Menten P, Struyf S, Wuyts A, Opdenakker G, Detheux M, Parmentier M, Durinx C, Lambeir AM, Neyts J, Liekens S, Maudgal PC, Billiau A, Van Damme J (2001) Amino- terminal truncation of CXCR3 agonists impairs receptor signaling and lymphocyte chemotaxis, while preserving antiangiogenic properties. Blood 98:3554-3561

14. Dwinell MB, Lugering N, Eckmann L, Kagnoff MF (2001) Regulated production of interferon-inducible T-cell chemoattractants by human intestinal epithelial cells. Gastroenterology 120:49-59

15. Auphan N, DiDonato JA, Rosette C, Helmberg A, Karin M (1995) Immunosupression by glucocorticoids: inhibition of NFkB activity through induction of IkB synthesis. Science 270:286-289

16. Mahida YR, Wu K, Jewell DP (1989) Enhanced production of interleukin 1-beta by mononuclear cells isolated from mucosa with active ulcerative colitis of Crohn's disease. Gut 30:835-838

17. Raddatz D, Bockemuhl M, Ramadori G (2005) Quantitative measurement of cytokine mRNA in inflammatory bowel disease: relation to clinical and endoscopic activity and outcome. Eur J Gastroenterol Hepatol 17:547-557

18. Raddatz D, Middel P, Bockemuhl M, Benohr P, Wissmann C, Schworer H, Ramadori G (2004) Glucocorticoid receptor expression in inflammatory bowel disease: evidence for a mucosal downregulation in steroid-unresponsive ulcerative colitis. Aliment Pharmacol Ther 19:47-61

19. Caldenhoven E, Liden J, Wissink S, Van de Stolpe A, Raaijmakers J, Koenderman L, Okret S, Gustafsson JA, Van der Saag PT (1995) Negative cross-talk between RelA and the glucocorticoid receptor: a possible mechanism for the antiinflammatory action of glucocorticoids. Mol Endocrinol 9:401-412

20. Raddatz D, Toth S, Schworer H, Ramadori G (2001) Glucocorticoid receptor signaling in the intestinal epithelial cell lines IEC-6 and Caco-2: evidence of inhibition by interleukin-1beta. Int J Colorectal Dis $16: 377-383$

21. Bantel H, Schmitz ML, Raible A, Gregor M, Schulze-Osthoff K (2002) Critical role of NF-kappaB and stress-activated protein kinases in steroid unresponsiveness. FASEB J 16:18321834

22. Egan LJ, Mays DC, Huntoon CJ, Bell MP, Pike MG, Sandborn WJ, Lipsky JJ, McKean DJ (1999) Inhibition of interleukin-1-stimulated NF-kappaB RelA/p65 phosphorylation by mesalamine is accompanied by decreased transcriptional activity. J Biol Chem 274:2644826453

23. Jobin C, Haskill S, Mayer L, Panja A, Sartor RB (1997) Evidence for altered regulation of I kappa B alpha degradation in human colonic epithelial cells. J Immunol 158:226-234

24. Yokoo T, Kitamura M (1996) Antioxidant PDTC induces stromelysin expression in mesangial cells via a tyrosine kinaseAP-1 pathway. Am J Physiol 270:F806-F811

25. Munoz C, Castellanos MC, Alfranca A, Vara A, Esteban MA, Redondo JM, de Landazuri MO (1996) Transcriptional upregulation of intracellular adhesion molecule-1 in human endothelial cells by the antioxidant pyrrolidine dithiocarbamate involves the activation of activating protein-1. J Immunol 157:35873597

26. Moon SK, Jung SY, Choi YH, Lee YC, Patterson C, Kim CH (2004) PDTC, metal chelating compound, induces G1 phase cell cycle arrest in vascular smooth muscle cells through inducing p21Cip1 expression: involvement of p38 mitogen activated protein kinase. J Cell Physiol 198:310-323

27. Parhar K, Ray A, Steinbrecher U, Nelson C, Salh B (2003) The p38 mitogen-activated protein kinase regulates interleukin-1betainduced IL-8 expression via an effect on the IL-8 promoter in intestinal epithelial cells. Immunology 108:502-512

28. Holtmann H, Winzen R, Holland P, Eickemeier S, Hoffmann E, Wallach D, Malinin NL, Cooper JA, Resch K, Kracht M (1999) Induction of interleukin-8 synthesis integrates effects on transcription and mRNA degradation from at least three different cytokine- or stress-activated signal transduction pathways. Mol Cell Biol 19:6742-6753 
29. Jung YD, Fan F, McConkey DJ, Jean ME, Liu W, Reinmuth N, Stoeltzing O, Ahmad SA, Parikh AA, Mukaida N, Ellis LM (2002) Role of P38 MAPK, AP-1, and NF-kappaB in interleukin1beta-induced IL-8 expression in human vascular smooth muscle cells. Cytokine 18:206-213

30. Stoeckle MY (1991) Post-transcriptional regulation of gro alpha, beta, gamma, and IL-8 mRNAs by IL-1 beta. Nucleic Acids Res 19:917-920
31. Nenci A, Becker C, Wullaert A, Gareus R, van Loo G, Danese S, Huth M, Nikolaev A, Neufert C, Madison B, Gumucio D, Neurath MF, Pasparakis M (2007) Epithelial NEMO links innate immunity to chronic intestinal inflammation. Nature 446:557-561

32. Greten FR, Eckmann L, Greten TF, Park JM, Li ZW, Egan LJ, Kagnoff MF, Karin M (2004) IKKbeta links inflammation and tumorigenesis in a mouse model of colitis-associated cancer. Cell 118:285-296 